\title{
Implementasi Algoritma K-Means Dalam Penentuan Prioritas Rehabilitasi Daerah Aliran Sungai Cipunagara
}

\author{
Odi Nurdiawan ${ }^{1}$, Fidya Arie Pratama ${ }^{2}$ \\ ${ }^{I}$ Dosen Program Studi Manajemen Informatika, STMIK IKMI Cirebon, Indonesia. \\ ${ }^{2}$ Dosen Program Studi Komputerisasi Akuntansi, STMIK IKMI Cirebon, Indonesia
}

\section{KEYWORDS}

Daerah Aliran Sungai, Algoritma K-Means Clustering, Lahan Kritis

\section{CORRESPONDENCE}

Phone: 085868991405

E-mail: odynurdiawan@gmail.com

\section{PENDAHULUAN}

Kekeringan merupakan salah satu masalah lingkungan hidup yang secara spesifik dihadapi daerah indramayu yang setiap tahun terjadi. Hal ini tentu saja mengganggu kegiatan pertanian masyarakat, terlebih diketahui bahwa potensi Kabupaten subang-indramayu banyak terletak pada hasil pertanian seperti padi. Ketersediaan sumber air salah satu kebutuhan, mengingat selain potensi unggulan pada bidang pertanian memerlukan air cukup banyak. Daerah aliran sungai cipunagara adalah salah satu alternatif sebagai sumber air tidak bisa manampung air dalam debit yang banyak, di beberapa daliran sudah mengalami kerusakan[8-9]

Berdasarkan identifikasi dan pemetaan lahan kritis di daerah aliran sungai cipunagara ditentukan berdasarkan parameter Perdirjen BPDASPS Nomor P.4/V-Set/2013 ialah wilayah daerah aliran sungai cipunagara dibagi menjadi 3 kawasan utama yaitu kawasan hutan lindung, kawasan budidaya pertanian dan kawasan lindung di luar hutan serta hutan produksi. Data kawasan pada tabel 1 menjelaskan bahwa Kawasan https://doi.org/10.30743/infotekjar.v4i1.1633
Budidaya Pertanian memiliki luas 106.801,47 Hektar, Kawasan Hutan Lindung memiliki luas 7.153,24 Hektar, dan kawasan hutan produksi memiliki 19.687,35 Hektar serta Kawasan lindung diluar 2.226,44 Hektar. Maka dari data tersebut Kawasan Budidaya Pertanian sangat dominan diwilayah subang dan indramayu serta wilayah yang dialiri sungai cipunagara. Hal tersebut menjadi salah satu sumber air bagi petani [4-5]

Tabel 1 Kawasan DAS Cipunagara

\begin{tabular}{lll}
\hline No & Kawasan & Luas $($ Ha) \\
\hline $\mathbf{1}$ & Budidaya Pertanian & $106.801,47$ \\
\hline $\mathbf{2}$ & Hutan Lindung & $7.153,24$ \\
\hline $\mathbf{3}$ & Hutan Produksi & $19.687,35$ \\
\hline $\mathbf{4}$ & Lindung diluar Kawasan & $2.226,44$ \\
\hline & TOTAL & $\mathbf{1 3 5 . 8 6 8 , 5 0}$ \\
\hline
\end{tabular}

Tabel 2 Parameter Tingkat Lahan Kritis

\begin{tabular}{llccl}
\hline No & $\begin{array}{l}\text { Parameter Penentuan } \\
\text { Lahan kritis }\end{array}$ & HL & BP & $\begin{array}{l}\text { KLLH dan } \\
\text { HP }\end{array}$ \\
\hline $\mathbf{1}$ & Penutupan Lahan & $\sqrt{ }$ & - & $\sqrt{ }$ \\
\hline $\mathbf{2}$ & Produktivitas & - & $\sqrt{ }$ & - \\
\hline
\end{tabular}

Attribution-NonCommercial 4.0 International. Some rights reserved 


\begin{tabular}{lllll}
\hline $\mathbf{3}$ & Lereng & $\sqrt{ }$ & $\sqrt{ }$ & $\sqrt{ }$ \\
\hline $\mathbf{4}$ & Tingkat Bahaya Erosi & $\sqrt{ }$ & $\sqrt{ }$ & $\sqrt{ }$ \\
\hline $\mathbf{5}$ & Manajemen & $\sqrt{ }$ & $\sqrt{ }$ & $\sqrt{ }$ \\
\hline $\mathbf{6}$ & Erovisitas Hujan (R) & - & - & - \\
\hline $\mathbf{7}$ & $\begin{array}{l}\text { Erosi yang diperoleh } \\
\text { (EDP) }\end{array}$ & - & - & - \\
$\mathbf{8}$ & Erodibilitas & - & - & - \\
\hline
\end{tabular}

Keterangan $: \mathrm{HL}=$ Hutan Lindung, $\mathrm{BP}=$ Budidaya Pertanian, KLLH = Kawasan Lindung diluar kawasan hutan, dan HP = Hutan Produksi

Salah satu solusi dalam menangani kekeringan diwilayah daerah aliran sungai cipunegara yaitu dilakukan rehabilitasi lahan kritis karena tingkat penutupan lahan, tinggkat bahaya erosi dan lereng sangat tinggi. Hal tersebut berdampak pada pertanian diwilayah subang-indramayu. Dalam melakukan rehabilitas perlu dilakukan pengelompokan wilayah lahan kritis, sedang maupun baik. Pengelompokan dilakukan menggunakan algoritma k-means. Data yang akan diambil dari Balai Besar Wilayah Sungai Citarum dan difokuskan pada Bina Pengelolaan Daerah Aliran Sungai Cipunagara dan Bendungan Salam Darma.

\section{STUDI PUSTAKA}

\section{Lahan Kritis}

Lahan kritis merupakan lahan yang telah mengalami atau dalam proses kerusakan fisik, kimia, atau biologi yang akhirnya dapat membahayakan fungsi hidrologi, orologi, produksi pertanian, pemukiman, dan kehidupan sosial ekonomi dari daerah lingkungan pengaruhnya.Peningkatan jumlah penduduk sejalan pula dengan meningkatnya kebutuhan akan lahan peruntukan pemukiman bagi tempat tinggal manusia, industri, maupun lahan pertanian sebagai sarana pemenuhan kebutuhan pangan manusia [7-10]

\section{Data Mining}

Data mining sebagai suatu proses eksplorasi dan analisis secara otomatis maupun semi otomatis terhadap data dalam jumlah besar dengan tujuan menemukan pola atau aturan yang berarti [1]

Algoritma K-Means

Algoritma K -means menggunakan proses secara berulang-ulang untuk mendapatkan basis data cluster. Dibutuhkan jumlah cluster awal yang diinginkan sebagai masukan dan menghasilkan titik centroid akhir sebagai output. Metode K-means akan memilih pola k sebagai titik awal centroid Secara acak atau random. Jumlah iterasi untuk mencapai cluster Centroid akan dipengaruhi oleh calon Cluster centroid awal secara random.Sehingga didapat cara dalam pengembangan algoritma dengan menentukan centroid Cluster yang dilihat dari kepadatan data awal yang tinggi agar mendapatkan kinerja yang lebih tinggi [17]

Berikut ini langkah-langkah yang terdapat pada algoritma K-Means [15]

a) Tentukan k sebagai jumlah cluster yang dibentuk

b) Tentukan $\mathrm{k}$ centroid (titik pusat cluster) awal secara random Penentuan centroid awal dilakukan secara random/acak dari objek-objek yang tersedia sebanyak k cluster, kemudian untuk menghitung centroid cluster ke-i berikutnya, digunakan rumus sebagai berikut :

$$
v=\frac{\sum_{i=1}^{n} x_{i}}{n} \quad ; i=1,2,3, \ldots n
$$

Dimana :

$$
\begin{aligned}
& v: \text { centroid pada } \text { cluster } x_{i} \text { : objek ke-i } \\
& n: \text { banyaknya objek/jumlah objek yang } \\
& \text { menjadi anggota } \text { cluster }
\end{aligned}
$$

c) Hitung jarak setiap objek ke masing-masing centroid dari masing- masing cluster. Untuk menghitung jarak antara objek dengan centroid dapat menggunakan Euclidian Distance.

$$
d(x, y)=\|x-y\|=\sqrt{\sum_{i=1}^{n}\left(x_{i}-y_{i}\right)^{2}} \quad ; i=1,2,3, \ldots, n
$$

Dimana; $x_{i}$ : objek x ke-i

$$
\begin{aligned}
& y_{i} \text { : daya y ke-i } \\
& n: \text { banyaknya objek }
\end{aligned}
$$

d) Alokasikan masing-masing objek ke dalam centroid yang paling dekat. Untuk melakukan pengalokasian objek kedalam masing-masing cluster pada saat iterasi secara umum dapat dilakukan dengan cara hard $\mathrm{k}$ - means dimana secara tegas setiap objek dinyatakan sebagai anggota cluster dengan mengukur jarak kedekatan sifatnya terhadap titik pusat cluster tersebut

e) Lakukan iterasi, kemudian tentukan posisi centroid baru dengan menggunakan persamaan

f) Ulangi langkah 3 jika posisi centroid baru tidak sama

\section{METODE PENELITIAN}

Diagram Alir Penelitian Dapat dilihat pada gambar xx

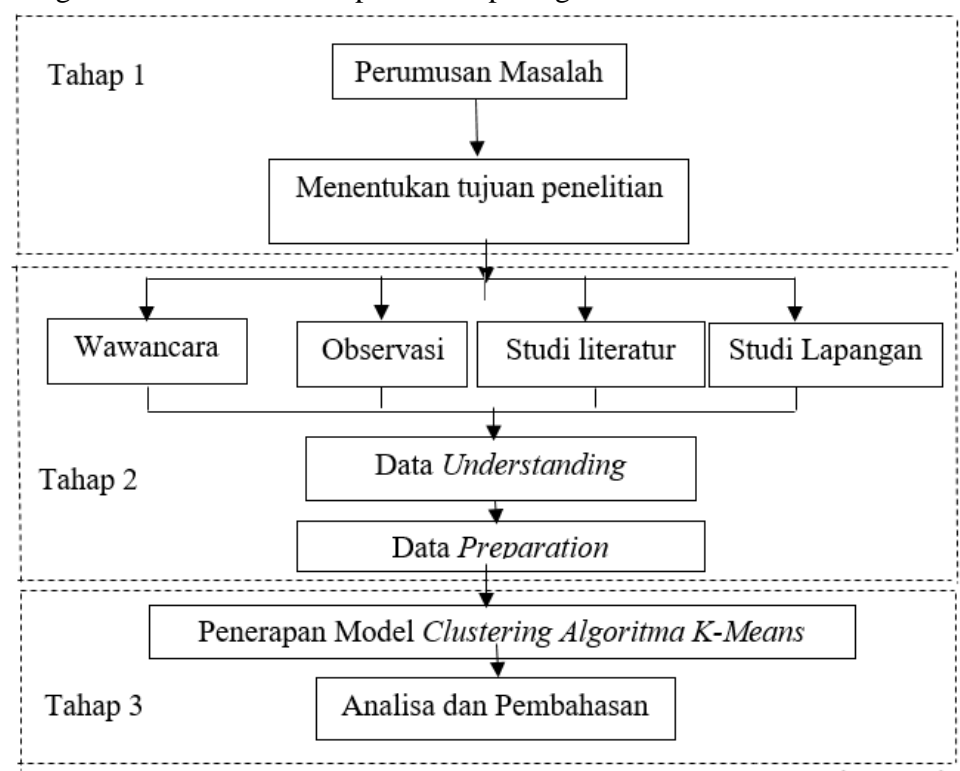

Gambar 1 Diagram Alir

\section{Tahap 1 (Satu)}

Penelitian Awal memiliki beberapa tahapan di antaranya :

a. Penentuan Objek Penelitian

b. Rumusan Masalah

c. Menentukan tujuan penelitian

2. Tahap 2 (Dua)

Pada tahap ini memiliki beberapa tahapan diantaranya : 
a. Observasi

b. Wawancara

c. Studi literatur

d. Studi Lapangan

e. Pemahaman Data (Data Understanding)

f. Data Preparation

3. Tahap 3 (Tiga

Penerapan Model Clustering Algoritma K-Means

\section{HASIL DAN PEMBAHASAN}

Lokasi

Penelitian ini dilakukan di wilayah DAS Cipunagara yang sebagian besar berada di Kabupaten Subang dan indramayu.Data yang digunakan berupa peraturan Perundang undangan, BPDAS Citarum pada tahun 2016 dan 2017, dan instansi - instansi lain yang berkaitan dengan data yang diperlukan.

Populasi dan Sampling

Penelitian yang akan digunakan menggunakan data Balai Besar Wilayah Sungai Citarum difokuskan pada Badan Pengelolaan Daerah Aliran Sungai Cipunagara pada tahun 2016 dan 2017, yang mencakup 29 Kecamatan dan 207, menggunakan teknik sampling jenuh artinya sampel semua anggota populasi digunakan sebagai sampel. Sample yang digunakan ialah 414 Record data.

Tabel 3 Dataset DAS Cipunagara

\begin{tabular}{llllllll} 
No & Kec & DS & PL & KL & TBE & PO & MAN \\
\hline $\mathbf{1}$ & Subang & Pegaden & 77 & 25 & 95 & 90 & $\begin{array}{l}\text { Lengka } \\
\mathrm{p}\end{array}$ \\
\hline $\mathbf{2}$ & Subang & Binong & 60 & 25 & 95 & 90 & $\begin{array}{l}\text { Lengka } \\
\mathrm{p}\end{array}$ \\
\hline $\mathbf{3}$ & Subang & $\begin{array}{l}\text { Cipunag } \\
\text { ara }\end{array}$ & 80 & 25 & 95 & 90 & $\begin{array}{l}\text { Lengka } \\
\mathrm{p}\end{array}$ \\
\hline$\ldots$ & $\ldots$ & $\ldots$ & $\ldots$ & $\ldots$ & $\ldots$ & $\ldots$ & $\ldots$ \\
\hline $\mathbf{4 1 4}$ & Anjatan & Anjatan & 60 & 25 & 56 & 56 & $\begin{array}{l}\text { Lengka } \\
\mathrm{p}\end{array}$ \\
\hline
\end{tabular}

Keterangan :

Kec : Kecamatan

DS : Desa

PL : Penutupan Lahan

KL : Kemiringan Lahan

TBE : Tingkat Bahaya Erosi

PO : Produktivitas

MAN : Manajemen

Preprocessing Data

Berdasarkan data set dilakukan pembobotan sesuai dengan

Permenhut Nomor P.32/Menhut-II/2009.
Tabel 4 Pembobotan

\begin{tabular}{|c|c|c|c|c|c|}
\hline NO & PL & KL & TBE & PO & MAN \\
\hline 1 & 4 & 2 & 95 & 5 & 5 \\
\hline 2 & 3 & 2 & 95 & 5 & 5 \\
\hline 3 & 4 & 2 & 95 & 5 & 5 \\
\hline$\cdots$ & $\cdots$ & $\cdots$ & $\cdots$ & $\cdots$ & $\cdots$ \\
\hline 414 & 3 & 2 & 95 & 5 & 5 \\
\hline
\end{tabular}

Hasil Normalisasi dari dataset, dapat dilihat pada tabel 5.

Tabel 5 Normalisasi

\begin{tabular}{cccccc}
\hline NO & $\mathbf{P L}$ & KL & TBE & PO & MAN \\
\hline $\mathbf{1}$ & 200 & 2 & 95 & 150 & 50 \\
\hline $\mathbf{2}$ & 150 & 2 & 95 & 150 & 50 \\
\hline $\mathbf{3}$ & 200 & 2 & 95 & 150 & 50 \\
\hline $\mathbf{4}$ & 150 & 2 & 95 & 150 & 50 \\
\hline $\boldsymbol{4}$ & $\ldots$ & $\ldots$ & $\ldots$ & $\ldots$ & $\ldots$ \\
\hline $\mathbf{4 1 4}$ & 100 & 2 & 95 & 150 & 50 \\
\hline
\end{tabular}

Penerapan Algoritma K-Means

Penerapan Algoritma K-means Menggunakan Software Rapidminer Versi 9. Langkah pertama ialah input data set dengan file spreadsheet (Microsoft Excel). Pembacaan file dataset tersebut menggunakan operator Read Exce yang ada pada Software Rapidminer, Gambar tersebut

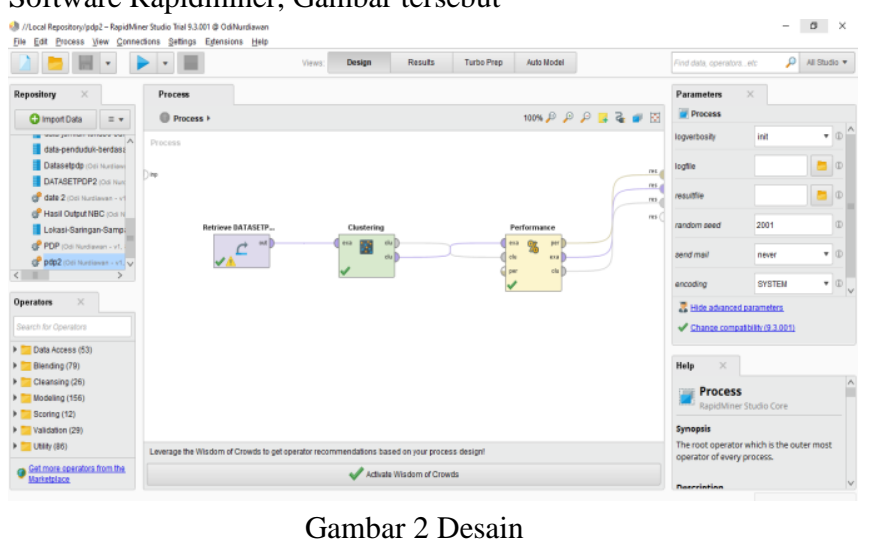

Parameter penerapan algoritma k-means pada penelitian ini sebagai berikut :

Tabel 6 Parameter

\begin{tabular}{cll}
\hline No & \multicolumn{1}{c}{ Parameter } & \multicolumn{1}{c}{ Value } \\
\hline $\mathbf{1}$ & K & 4 \\
\hline $\mathbf{2}$ & Max Run & 10 \\
\hline $\mathbf{3}$ & Measure type & Numerical measurement \\
\hline $\mathbf{4}$ & Numerical measure & EuclideanDistance \\
\hline $\mathbf{5}$ & Max optimization step & 100 (default) \\
\hline
\end{tabular}

Hasil Results model Algoritma K-means terhadap 4 (empat) Cluster data tersebut dapat dilihat pada gambar 3. 


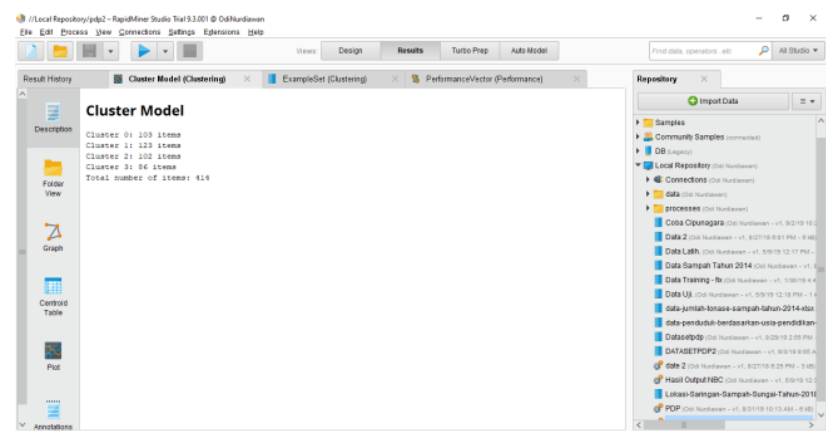

Gambar 3 Cluster Model

Hasil Centroid dengan 4 (empat) Cluster pada Cluster Model KMeans dapat dilihat pada gambar 4

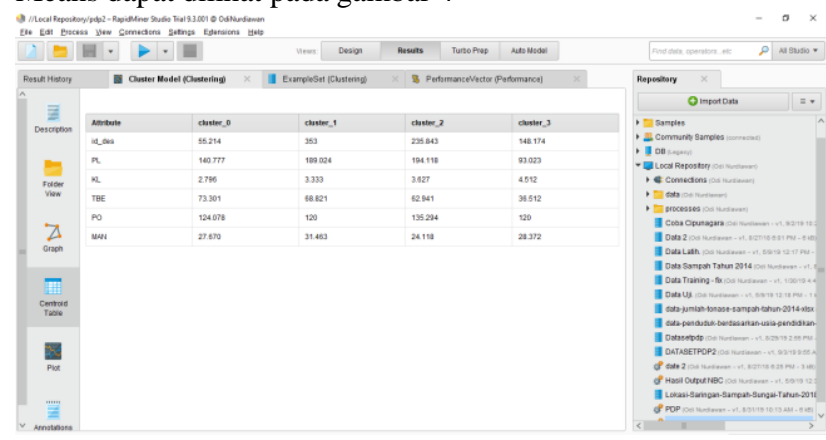

Gambar 4 Centroid

Hasil Plot dengan 4 (empat) Cluster pada Cluster Model K-Means dapat dilihat pada gambar 5

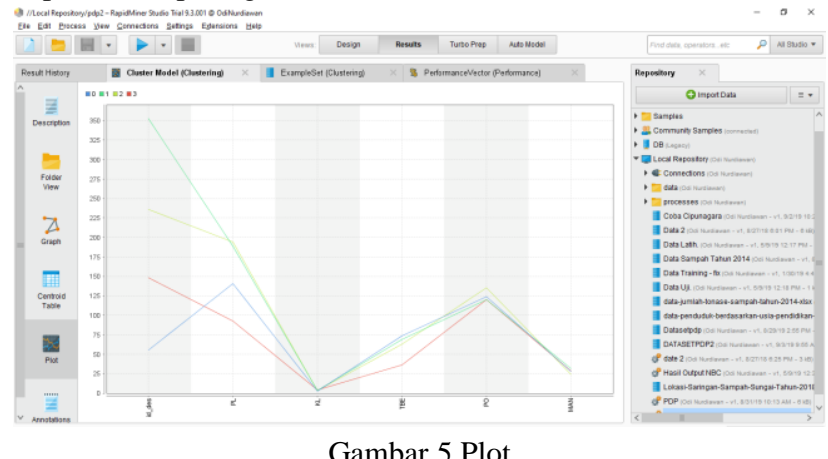

Hasil Set Cluster berdasarkan Statistic dengan 6 (Enam) Atribut yang akan digunakan, diantaranya Id_desa, PL (Penutupan Lahan), KL (Kemiringan Lahan), TBE (Tingkat Bahaya Erosi), PO (Prodiktivitas), MAN (Manajemen), data set cluster dapat dilihat pada gambar 6

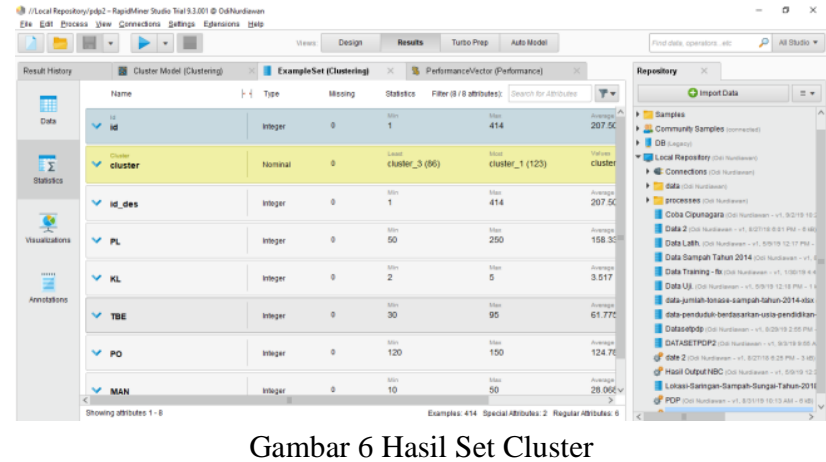

Hasil Set Cluster visualizations berdasarkan grafik scatter Id_Desa, grafik tersebut dapat dilihat pada gambar 7

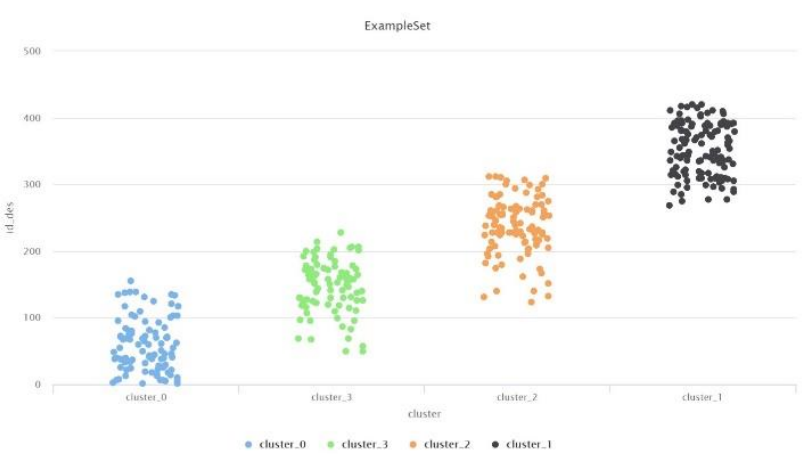

Gambar 7 Hasil Set Cluster

Hasil Set Cluster visualizations berdasarkan grafik scatter KL (Kemiringan Lahan), grafik tersebut dapat dilihat pada gambar 8

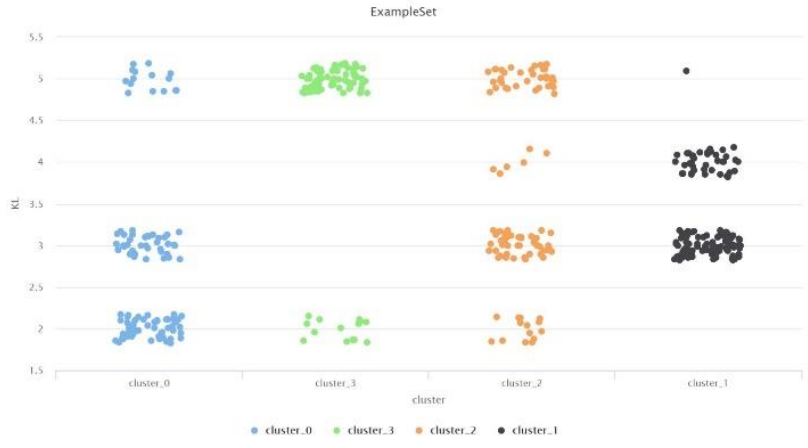

Gambar 8 Hasil Set Cluster

Hasil Set Cluster visualizations berdasarkan grafik scatter MAN (Manajemen), grafik tersebut dapat dilihat pada gambar 9

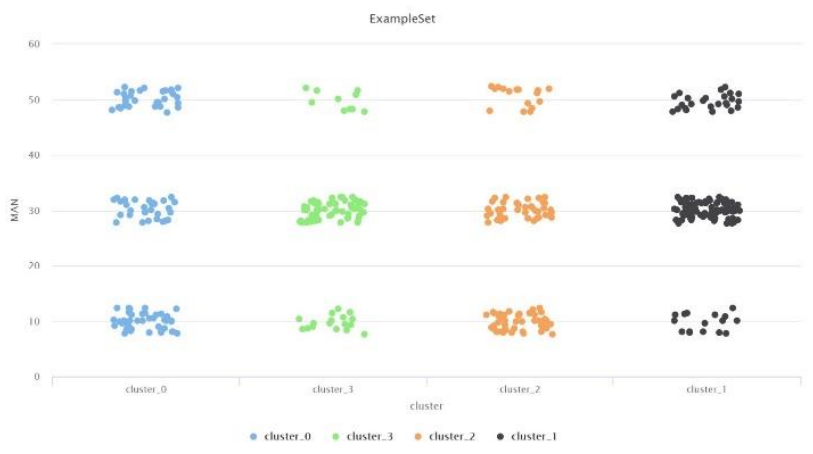

Gambar 9 Hasil Set Cluster

Hasil Set Cluster visualizations berdasarkan grafik scatter PL (Penutupan Lahan), grafik tersebut dapat dilihat pada gambar 10

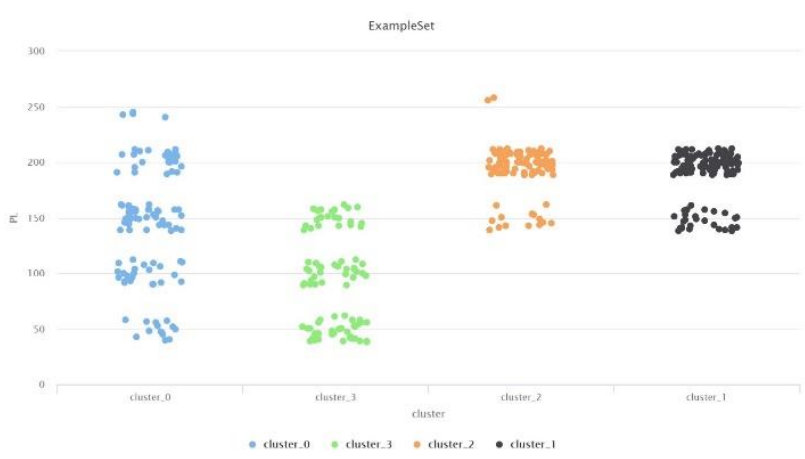

Gambar 10 Hasil Set Cluster

Hasil Set Cluster visualizations berdasarkan grafik scatter PO (Produktivitas), grafik tersebut dapat dilihat pada gambar 11

Odi Nurdiawan 


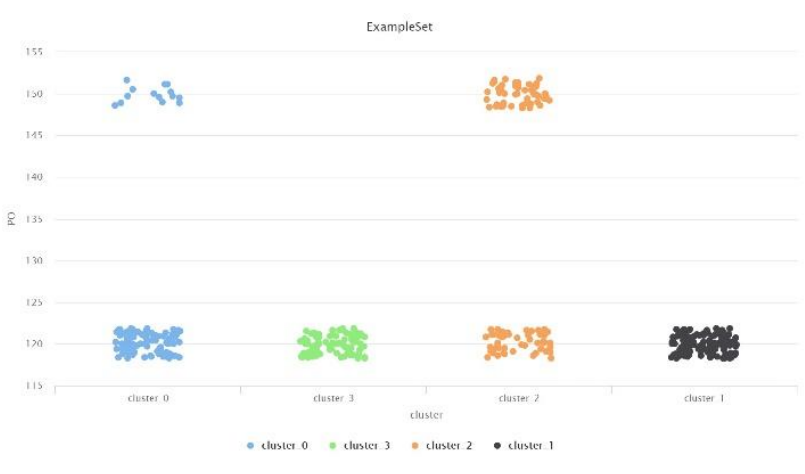

Gambar 11 Hasil Set Cluster

Hasil Set Cluster visualizations berdasarkan grafik scatter TBE (Tingkat Bahaya Erosi), grafik tersebut dapat dilihat pada gambar 12

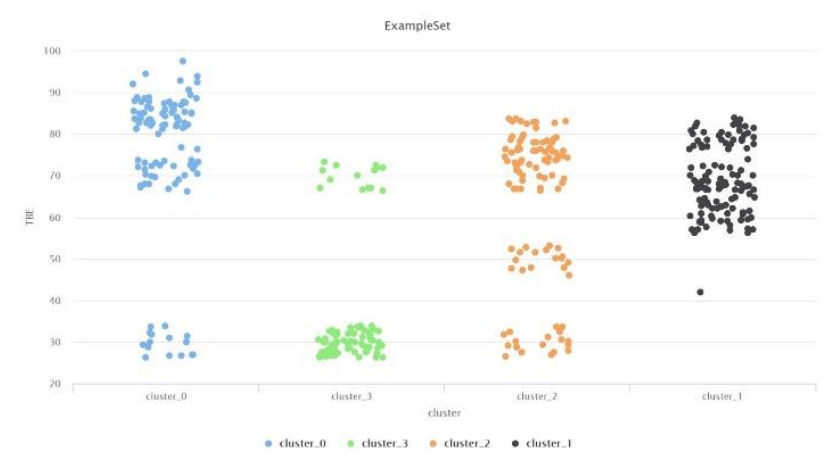

Gambar 12 Hasil Set Cluster

Hasil Performance Vector berdasarkan rata rata setiap cluster, data tersebut dapat dilihat pada gambar 13

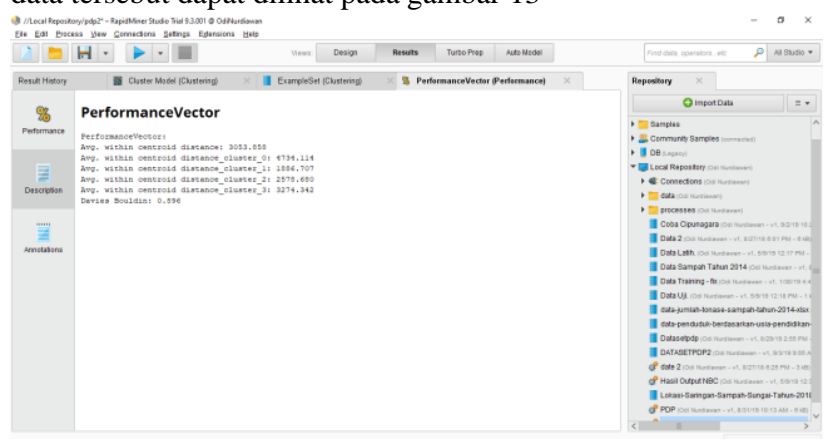

Gambar 13 Hasil Performance Vector

Pembahasan

Berdasarkan pemaparan diatas tersebut untuk mengevaluasi kinerja cluster menggunakan Operator Cluster Distance Performance mengambil model cluster centroid dan mengatur cluster sebagai input dan mengevaluasi kinerja model berdasarkan centroid cluster Operator ini digunakan untuk evaluasi kinerja metode pengelompokan berdasarkan centroid. Hasil dari Cluster Distance Performance menjelaskan bahwa performance vector pada Avg.within centroid distance sebesar 3058,858. Avg.within centroid distance_cluster_O sebesar 4734,114. Avg.within centroid distance_cluster_1 sebesar 1886.707. Avg.within centroid distance_cluster_2 sebesar 2578,680. Avg.within centroid distance_cluster_3 sebesar 3274.342. sedangkan Davies Bouldin sebesar 0.896. maka cluster dengan jarak intra-cluster yang rendah (kesamaan intra-cluster yang tinggi) dan jarak antar-cluster yang tinggi (kesamaan antarcluster yang rendah) akan memiliki indeks Davies-Bouldin yang

80 Odi Nurdiawan rendah, algoritma clustering yang menghasilkan kumpulan cluster dengan indeks Davies-Bouldin terkecil kumpulan cluster terbaik adalah cluster_l dengan nilai 1886.707 .

Hasil cluster terbaik adalah cluster_l maka perioritas rehabilitasi daerah aliran sungai cipunagara, dapat dilihat pada tabel 7

Tabel 7 Cluster 1

\begin{tabular}{cccl}
\hline No & No Id & Clauster 1 & \multicolumn{1}{c}{ Nama Desa } \\
\hline $\mathbf{1}$ & 292 & cluster_1 & Cisaat \\
\hline $\mathbf{2}$ & 293 & cluster_1 & Curugrendeng \\
\hline $\mathbf{3}$ & 294 & cluster_1 & Sarireja \\
\hline $\mathbf{4}$ & 295 & cluster_1 & Sanca \\
\hline $\boldsymbol{\cdots}$ & $\ldots$ & $\ldots$ & $\ldots$ \\
\hline $\mathbf{1 2 3}$ & 296 & cluster_1 & Cimanglid \\
\hline
\end{tabular}

\section{KESIMPULAN}

Hasil simpulan pada penelitian ini bahwa rehabilitasi daerah aliran sungai cipunagara dengan menggunakan metode algoritma k-means dapat mengevaluasi kinerja cluster menggunakan Operator Cluster Distance Performance mengambil model cluster centroid dan mengatur cluster sebagai input dan mengevaluasi kinerja model berdasarkan centroid cluster Operator ini digunakan untuk evaluasi kinerja metode pengelompokan berdasarkan centroid. Hasil dari Cluster Distance Performance menjelaskan bahwa performance vector pada Avg.within centroid distance sebesar 3058,858. Avg.within centroid distance_cluster_O sebesar 4734,114. Avg.within centroid distance_cluster_1 sebesar 1886.707. Avg.within centroid distance_cluster_2 sebesar 2578,680. Avg.within centroid distance_cluster_3 sebesar 3274.342. sedangkan Davies Bouldin sebesar 0.896. maka cluster dengan jarak intra-cluster yang rendah (kesamaan intra-cluster yang tinggi) dan jarak antarcluster yang tinggi (kesamaan antar-cluster yang rendah) akan memiliki indeks Davies-Bouldin yang rendah, algoritma clustering yang menghasilkan kumpulan cluster dengan indeks Davies-Bouldin terkecil kumpulan cluster terbaik adalah cluster_l dengan nilai 1886.707

\section{ACKNOWLEDGMENT}

Peneliti Mengucapkan Banyak Terimakasih kepada Kementerian Riset Teknologi dan Pendidikan Tinggi atas Hibah Penelitian Dosen Pemula, STMIK IKMI Cirebon, Balai Besar Wilayah Sungai Citarum, Bina Penglolaan Daerah Aliran Sungai Cipunagara dan Bendungan Salam Darma Serta Kelompok Tani wilayah Gabus Wetan.

\section{DAFTAR PUSTAKA}

[1] Larose, Daniel T, 2005, Discovering Knowledge in Data: An Introduction to Data Mining, John Willey \& Sons. Inc

[2] Agusta, Y. 2007. K-means - Penerapan, Permasalahan dan Metode Terkait. Jurnal Sistem dan Informatika Vol. 3 (Februari 2007): 47-60.

[3] Kementerian Kehutanan. 2013. Peraturan Direktur Jenderal Bina Pengeloaan Daerah lauran Sungai dan Perhutanan Sosial Nomor : P 4/V-Set/2013 tentang 
Petunjuk Teknis Penyusunan Data Spasial Lahan Kritis. Jakarta (ID) : Kemenhut

[4] Peraturan Direktur Jendral Bina Pengelolaan Daerah Aliran Sungai dan Perhutanan Sosial Nomor. P.4/VSet/2013. Petunjuk Teknis Penyusunan Data Spasial Lahan Kritis. Jakarta: BPDASPS

[5] Peraturan Menteri Kehutanan Nomor. P.32/MenhutII/2009. Petunjuk Teknis Penyusunan Data Spasial Lahan Kritis. Jakarta: Kementrian Kehutanan.

[6] Poerwowidodo. 1990. Telaah Kesuburan Tanah. Bamdung: Angkasa

[7] Hanifah, K. A., 2012. Dasar-dasar Ilmu Tanah. Penerbit PT Raja Grafindo Persada. Jakarta.

[8] Arsad, Sitanala. 1989. Konservasi Tanah dan Air.Bogor: IPB Press

[9] Hardjowigeno, S. 2007. Ilmu Tanah. Jakarta: Akademika Pressindo. 296 Halaman

[10] Hardjowigeno, S., Subagyo, H., dan Luthfi, R.M. 2004. Morfologi dan Klasifikasi Tanah Sawah. Di dalam: Tanah Sawah dan Teknologi pengelolaannya. Pusat Penelitian Tanah dan Agroklimat. Departemen Pertanian : Bogor.

[11] Hardjowigeno, S. dan M. L. Rayes. 2005. Tanah Sawah Karakteristik, Kondisi dan Permasalahan Tanah Sawah di Indonesia. Bayumedia Publishing. Malang.

[12] Sunarto. 1991. Geomorfologi Pantai. Pusat Antar Universitas Ilmu Teknik UGM. Yogyakarta

[13] Sarief, S. 1980. Fisika Tanah Dasar. Serial Publikasi Ilmu-ilmu Tanah. Fakultas Pertanian. Universitas Padjajaran:Bandung. 120 hal.

[14] Utomo, W.H. 1989. Erosi dan Konservasi Tanah, IKIP Malang, Malang.

[15] Turban, Efraim, et al. 2005. Decision Support Systems and Intelligent Systems 7th Ed. New Jersey : Pearson Education

[16] Madhulatha, T.S., 2012. AN OVERVIEW ON CLUSTERING METHODS. IOSR Journal of Engineering, II(1), pp.719-25

[17] HUNG, C.M., WU, J., CHANG, J.H. \& YANG, D.L., 2005. An Efficient k-Means Clustering Algorithm Using Simple Partitioning. JOURNAL OF INFORMATION SCIENCE AND ENGINEERING, XXI(1), pp.1157-77.

[18] Bataineh, K.M., Naji, M. \& Saqer, M., 2011. A Comparasion Study between Various Fuzzy Clustering Algorithms. Jordan Journal of Mechanical and Industrial Engineering, V(4), pp.335-43.

[19] Varghese, B.M., J, J.T., A, U. \& K, J.P., 2011. Clustering Student Data to Characterize Performance Patterns. International Journal of Advanced Computer Science and Applications, I(3), pp.138-40.

[20] Bangoria, B., Mankad, N. \& Pambhar, V., 2013. A Survey on Efficient Enhanced K-Means Clustering Algorithm. International Journal for Scientific Research \& Development, I(9),pp.1698-700.

[21] Ediyanto, Mara, M.N. \& Satyahadewi, N., 2013. Pengklasifikasian Karakteristik Dengan Metode KMeans Cluster Analysis. Buletin Ilmiah Mat. Stat. dan Terapannya, II(2), pp.133-36. 